Peer review: This article has been subject to a double-blind peer review process

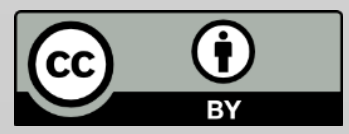

Copyright notice: This article is issued under the terms of the Creative Commons Attribution License, which permits use and redistribution of the work provided that the original author and source are credited.

You must give appropriate credit (author attribution), provide a link to the license, and indicate if changes were made. You may do so in any reasonable manner, but not in any way that suggests the licensor endorses you or your use. You may not apply legal terms or technological measures that legally restrict others from doing anything the license permits.

https://creativecommons .org/licenses/by/4.0/

\section{Figures of Thought in Marjane Satrapi's Persepolis and Riad Sattouf's The Arab of the Future}

\section{Doro Wiese}

School of Modern Languages and Cultures, University of Warwick, UK

Correspondence: Doro.Wiese@warwick.ac.uk

ORCID: 0000-0003-2016-5569

\begin{abstract}
This article takes Deleuze and Guattari's ideas on art's inventive function as a point of departure to analyse two graphic narratives that undermine ideas about truthfulness: Marjane Satrapi's Persepolis and Riad Sattouf's The Arab of the Future. It is argued that these allegedly autobiographical memoirs undermine genre conventions to create an implied readership who co-witnesses Satrapi's and Sattouf's experiences of oppression, racism, and war during their respective childhoods. It is shown how Satrapi and Sattouf undermine the autobiographical pact through graphic narrative's 'figures of thought', a term introduced to capture the formal, thematic, and narrative possibilities of comics and graphic literature to make readers come into contact with unforeseen visions-and to possibly think anew. Specific attention is paid to the narrative voice, which in Satrapi's and Sattouf's works often goes beyond the personal perspective to account for collective experiences, as well as to the use of colour and line work that add critical layers to the stories told. In line with Deleuze and Guattari's arguments, the poetic, which is the productive function of art, is shown to go beyond questions of truthfulness and falseness, allowing for new ways of thinking and for the creation of new worlds.
\end{abstract}

Keywords: truthfulness and falseness; the autobiographical pact; comic philosophy; the possibilities of art to invoke thought; fabulation 
In What is Philosophy? (Deleuze et al., 1994), Gilles Deleuze and Félix Guattari examine the critical possibilities of thought inherent in philosophy, science and art. While philosophy creates concepts and science creates functions, art creates affects and sensations. These affects and sensations are not conventional feelings. Nor does art depict either preconceived perceptions or memories. Human experience is not depicted in art but is instead subjected to complex processes that lead to transformations. For Deleuze and Guattari (1994), works of art have productive possibilities since they can entice recipients, through the creation of new worlds, to think otherwise. Works of art can add new, neglected, or forgotten narratives to historical consciousness and future imaginations, and possibly give rise to a vision in which social, political, individual problems are framed differently. This means that works of art, through their creative possibilities, complicate the contested line between truthful and false narratives. Creations, fabulations, fictions, inventions they all can add something to the remembered past, the experienced present and the envisioned future; they can produce new perceptions and sensations, and forge new relationships to the world. And while artworks can be used to falsify historical events, to spread hurtful ideologies, and to distort memories, these misuses do not delimit the arts' capacity. Especially when works of art are labelled and self-reflexively announce themselves as fictional, when they do not claim to be truthful representations, then they open up possibilities that extend beyond truthfulness and falseness (Wiese, 2014).

In this article, I want to demonstrate fiction's productiveness through an analysis of two graphic narratives that share many stylistic and thematic characteristics and yet are fundamentally different: Marianne Satrapi's two-volume comic-book Persepolis $(2003,2004)$ and Riad Sattouf's four volumes of The Arab of the Future $(2015,2016,2018,2019)$. Both graphic narratives are at least ostensibly autobiographical; they depict childhoods and thus create a certain horizon of expectation for readers. As Phillipe Lejeune has pointed out in Le pacte autobiographique (1975), readers of autobiographies assume that the author has the same identity as the narrative voice and/or the narrated character. Furthermore, autobiographies are imbued with a certain claim to truthfulness. As selfnarratives, the autobiography is also closely related to the novel of development and education-the Bildungsroman. As we shall see, Persepolis and The Arab of the Future complicate the autobiographical pact by deceiving ideas about the self through emphasis, exaggeration and fabulation. As narratives that bear witness to transnational migration and mobility, both comics also challenge national self-constructions as everyday myths. Since this unmasking takes place visually, I will use the term 'figures of thought' to refer to Deleuze and Guattari's ideas about the 
visionary power of artistic expressions. Nevertheless, 'figures of thought' is not an adopted term, but rather a conceptual intervention on my part, which relates to several discussions simultaneously. On the one hand, this concerns Deleuze and Guattari's philosophy of art, whose 'conceptual personae'- 'agents of enunciation' that 'produce movement by thinking' (1994: 64-5) - I would like to expand with the 'figures of thought' term. On the other hand, this article is also intended to provide a conceptual contribution to the reading of comics and graphic literature. Since the latter often deals with figures-stylistic figures as well as fictitious figures in graphic texts created from strokes, lines, colour or contrast-the term 'figures of thought' allows me to link formal, stylistic, thematic devices and thought with each other effortlessly. By focussing on the conjunction of visual and narrative elements, I will look at 'a distinct narratological configuration' offered by graphic literature (Groensteen, 2013: 81). Comic philosophy-that is what I am getting at. What percepts and affects do those 'figures of thought' evoke that are embedded in graphic fiction? And what possibilities for thinking does the specific mediality of comics open up? To demonstrate which narrative and stylistic choices evoke 'figures of thought', I will first outline how Persepolis, as well as The Arab of the Future, undermine the autobiographical pact-a reading contract which invites readers to see author, narrator, and protagonist as being identical. In the case of Persepolis as well as The Arab of the Future, even academic critics have made an autobiographical pact when analysing those graphic novels (cf. Chute, 2008; Friedman, 2013; Gilmore, 2011; Whitlock, 2007). Then, I will show how both graphic narratives appeal by way of affect to their audience through formal and narrative choices like line work, colour, and narrative perspective. It should be stressed that these stylistic and narrative devices are medium-specific for graphic literature that is defined as a 'specific conjunction of visual and verbal text' (Whitlock, 2006: 966). Oral or written literature can only express the respective equivalentsthrough style, description, point of view-linguistically. The former has, differently to graphic literature, no access to icon or indexical representation unless it uses visual registers.

Riad Sattouf's four volumes of The Arab of the Future tell the story of Riad, born in 1978, a blond, sensitive, irresistibly cute child, who at the age of two leaves France with his parents to go first to Libya and then to the Syrian homeland of his father Abdel-Razak. Riad's father, Abdel-Razak, received his doctorate in history at the Sorbonne when he met Riad's mother, Clémentine. Abdel-Razak is more like a caricature than a character. $\mathrm{He}$ is characterised above all by his inability to assess situations realistically and therefore makes one wrong decision after another. These misjudgements, in turn, are what drive the story forward, for it is usually Riad, his mother Clémentine and his brother Yahya who have to deal with 
the consequences of these errors and wrong estimations. Abdel-Razak, for example, believes in the absolute cohesion of the family, even though he is cheated of his family inheritance by his own brother and little Riad is often called a Jew and beaten up by his cousins. Last but not least, AbdelRazak has an unshakeable belief that the Arab of the future would be educated in school to a superior, pan-Arab position towards the West. The entire second volume of The Arab of the Future conveys this belief as an illusion: the primary school teacher hits children on the hands with a stick, leaves them standing in the corner, calls them traitors to the people and humiliates them. Girls do not go to school, nor do those children who have to herd goats. Every day, the children have to scream their lungs out to shout the national anthem and learn to read the Koran, even though they do not understand classical Arabic. In short: the Arab of the future goes to school, as Abdel-Razak vociferously announces at the end of the first volume, but the education that the children there receive consists of experiencing violence.

Persepolis tells the experience of living under a violent political regime. In the first volume The Story of a Childhood, the main character Marjane grows up in a sheltered, liberal home in Tehran, which supports the 1979 revolt against the Shah. But soon after the Shah's fall, Revolutionary Guards and thus a theocratic regime took over power in Iran. It is shown how friends of the family, who had just come out of prison as political prisoners, had to leave the country covertly. Others are again captured or murdered. With the invasion of Iraq, a war begins in which children are sent to the front. In schools, girls have to wear veils and sewn balaclavas. When the rebellious Marjane starts an argument with a teacher, her parents decide to send her to a French grammar school in Vienna. The transition from childhood to adolescence is initiated by the incision of exile, the significance of which is explored in the second volume of Persepolis. Here the experience of homelessness is central. Already the first taxi ride from the airport into Vienna, when Marjane is picked up by exiled friends of the family, is a clash of worlds. While Marjane is happy not to be subjected to any more repression at school, Shirin, who is the same age, raves about flavoured lipsticks and earmuffs. For Marjane, these banalities in times of war mean a betrayal that she too will soon have to commit. Her everyday life is too far removed from the events in Iran. In order to make friends and feel like she belongs, she smokes joints and cuts her hair punk-style. She lies to her parents on the phone. Whenever there are pictures from Iran on television, she changes the program. She gets to know gays and anarchists and her first boyfriend. Faced with recurring racism and her first separation, she puts on a headscarf and shrugs off Europe: '... I needed so badly to go home' (Satrapi, 2004: 91). 
Riad Sattouf's The Arab of the Future has received numerous awards, has been translated into sixteen languages and was highly praised in the press. ${ }^{i}$ In Le Monde, Frédéric Potet described The Arab of the Future as a worthy parent of current developments in autobiographical comics (2015), and critics in the Guardian, the New York Times and The New Yorker also sang the praises (cf. Cooke, 2016, Senior, 2016; Shatz, 2015). Persepolis is now one of the award-winning classics of comic art that has been discussed in essays and monographs by many well-known scholars of visuality and textuality (cf. Chute, 2008; Friedman, 2013; Gilmore, 2011; Whitlock, 2007). .i Even in these interpretations, Persepolis is consistently referred to as an autobiography. This might be the case because, as narratologists like Cohn (1990) and Genette (1990) have pointed out, there is no intrinsic distinction between a fictional or an actual autobiography. This means that, when narrator, character, and author of a written work share the same name, readers, including academic scholars, will expect to read an autobiography (see Löschnigg, 2019: 104). Is Persepolis, however, telling a personal life-story? In a Spiegel Online interview with Sonja Ernst, Satrapi stated that what she describes in Persepolis is 'merely a situation.' She is primarily 'a person who has witnessed revolution and war' (Ernst, 2005; my translation). Strictly speaking, Persepolis is much more than just a personal life-story; it is the testimony of a perception in which one's own history can always stand in for others because it demonstrates social conditions. Satrapi is therefore for graphic narratives what Brecht was for theatre when he invented its epic form (Brecht et al., 1978): a transformer of formal possibilities, a translator into social space. In fact, she has never claimed biography as a genre for Persepolis but instead described her work in the Spiegel interview as 'auto-fiction': a definition that connects well with Deleuze and Guattari's ideas on fiction's potential.

Returning to the inventive possibilities of fictional accounts, and to graphic narratives' 'figures of thought' outlined at the beginning, it is important to deconstruct the 'autobiographical pact' made by the critics, and to expand the-extremely positive-critiques of Satrapi and Sattouf. This concerns above all arguments which, in my opinion, allow the extraordinary explosive power of graphic novels and their artistic expressiveness to flow into the figure of the child narrator, so that the biting criticism of both authors on autocratic and totalitarian regimes is not perceived in its entirety. Satrapi and Sattouf undermine genre-expectations and use the visual repertoire of graphic narratives - their 'figures of thought' - to call forth readers able to oppose the intolerable situation of nationalist exclusions and hostilities.

The 'autobiographical pact' was introduced into narratology by Phillipe Lejeune (1975) and refers to the equation of authors with the narrative voice and/or the narrated character. If, for example, author Riad Sattouf 
introduces a narrative voice into The Arab of the Future that tells the story of character Riad Sattouf, then all three narrative positions are understood to be identical. Likewise, the author Marjane Satrapi is seen as an older version of the child and teenager Marjane. For according to the autobiographical pact, the story runs chronologically from a younger firstperson narrator located in the distant past to an adult first-person narrator belonging to a more recent past or possibly, as author, even to the present. However, it is precisely this chronology that complicates the assumption that the narrated story of a biography belongs to the past. Although Riad Sattouf, for example, always emphasises in interviews that he tried to take the limited perspective of a child in The Arab of the Future (cf. Chrisafis, 2016; Dueben, 2016; Mirakhor, 2017), a commentator makes her/himself felt here and there within the story when s/he corrects the child's statements and thus makes her/himself felt as an extra-diegetic, omniscient narrator. It is this commenting narrator who directs the narrative since $s /$ he makes it accessible to us. The Arab of the Future is, therefore, from the narrative perspective taken, the Arab of the present, perhaps even already the Arab of the past. For it makes a difference whether a narrative is told progressively or retrospectively; what was in the future for little Riad, narrated figure, in 1984, can be in the past for the adult Riad, either narrator or author. In Persepolis, too, a commenting narrator has the same effect on the graphic novel's temporalization, since $\mathrm{s} /$ he is chronologically closer to the present and possibly also reflects it. The fact that both narratives, Persepolis and The Arab of the Future, also refer to historical dates and events, wherefore they can be integrated into a historical course of time, is a further argument for the difficulty of viewing them as pure biographies: these references point to the interweaving of social events and a life's journey.

Sattouf's reference to the caricature also undermines the autobiographical pact, because he refers back to the non-biographical knowledge of the readers. His characters have cucumber noses, revolver hair, eggheads and handle ears so that his portrayal can immediately be deciphered as caricature-like. He thereby makes use of the medium-specificity of graphic literature that normally 'performs identity visually in the third person' by creating an avatar, an 'I-con' (Chaney, 2011: 23; quoted in Klepper, 2019: 442). This creates an 'ironic authentication' (Hatfield, 2005: 124; quoted in Klepper, 2019: 442) that can ironize either speaker or situation through excess, cliché or inadequacy. Sattouf's way of showing and telling exaggerates orientalist clichés to the point of intolerability, thereby destroying claims to their veracity, purportedly told from the perspective of a 'native informant' (Shatz, 2003). Furthermore, the history of form can also shape the expectations of readers: they have read Hergé's Adventures of Tintin (1929-1976), for example, and are familiar with its ligne claire, 
the clear and simple lines that largely dispense with embellishments and hatching, which, according to Scott McCloud (1994), through its sparing design, offer readers easily accessible identification. Persepolis is another example of the ligne claire that Satrapi uses to enable readers to identify smoothly with the characters narrated. For as we will see, Satrapi is particularly concerned with involving readers in a collective that is opposed to the rule of the mullahs. The two graphic narratives challenge national self-constructions as everyday myths. This establishes a readerly collective that is fabulated, as I will show through an analysis of colour and perspective.

Sattouf's colour scheme is insofar striking in that he tells the story of Riad and his family in monochrome, only changing colour when switching to a different national setting. Episodes in France take place against a blue background, episodes in Libya against a yellow one and episodes in Syria against a background of watered-down pink, with colour splashes of red or green. These colours evoke affects that can be associated with the figures of thought conjured up in the title. It must be considered that colours in themselves have no meaning: they only acquire their meaning in interaction with other signifiers (see Baetens, 2011; Baetens et al., 2015; Wiese, 2016). As Michel Pastoureau argues, 'colours foremost are conventions, tags, social codes. Their primary function is to distinguish, to classify, to associate, to oppose, to hierarchise' (Pastoureau, 2010: 69). This means that colour is entangled in power and politics, and helps to build up symbolic functions (see Andersen et al., 2015). In The Arab of the Future, colour signals a change of location across national borders. Through the use of colour, national settings are identified as fundamentally different, although their difference is marked by asignificant colours, whose meaning cannot be clearly defined. For who could clearly say what it means that Syria is penetratingly coloured pink and Libya yellow?

Precisely because colour only acquires its meaning in the play with other signifiers, its use in Sattouf's comic books illustrates a misguided logic. For in The Arab of the Future it is not the national settings that are different from each other, but the colours that are assigned to them. In this way, Sattouf exposes the secondary meaning that is inherent in many cultural signs. They do not only acquire their meaning in play with other linguistic signs but are, according to Roland Barthes' Mythologies (Barthes, 1957), embedded in a meta-language, which gives the signifiers a mythical meaning beyond their linguistic connotation. This process of signification also applies to nation-states. They differ from one another not only through their linguistic signifiers like 'France' or 'Libya' but also through the everyday myth of national differences, which creates a feeling of solidarity and an 'imagined community' (Anderson, 2016) between people 
of one nation and a sense of separation from people of other nations. Sattouf takes up this everyday myth and translates it one-to-one into a colour scheme: one nation corresponding to one colour without nuances. Sattouf's colouring demonstrates how absurd and rigid the idea of a clear national distinctiveness is and reveals it as a myth.

It is this visual straitjacket used in Sattouf's comic books that creates an affect which is better apprehended via the concept of 'figures of thought.' As said at the beginning, Deleuze and Guattari believe that artists create affects, precepts, and sensations that cannot be reconciled with familiar feelings, perceptions, or preconceived ideas. For them, it is the task of artists to slit open the umbrella that constitutes the known and protective firmament of our lives and to frame their visions of an underlying reality anew, thus creating new sensations. Sattouf's artistic achievement, however, consists in doing exactly the opposite of what distinguishes artists in Deleuze and Guattari's description: namely that they destroy the known firmament (1994: 203-04). Instead of cutting open the protective umbrella, which is inscribed with conventions and opinions and shields from a view of the celestial chaos, Sattouf dips the umbrella in monochrome national colours and then paints it with a host of caricatures. Within the narrative, these caricatures may well prove to be anti-Semitic, intolerant, corrupt, contemptuous of women and narrow-minded. Indeed, Sattouf's depiction of Libya and Syria has been charged for being racist, xenophobic, and Islamophobic, as well as for reinforcing stereotypes about Arab people (cf. Bonnefoy, 2015). Yet from my perspective, Sattouf gives these stereotypical depictions of the Arab world a surprising turn by intensifying them to the point of intolerability. If we follow this interpretation, it is precisely the constant repetition of stereotypes that characterises them as untenable and unbearably rigid. Sattouf thus illustrates the intolerability of stereotypes by repeating the self-same ideas repeatedly, thereby further intensifying their effect. And it is precisely this approach that affects us as readers and that enables us to think.

With the latter description, I refer to a distinction between affection and affect made by Baruch Spinoza (2011: 93-323, 1677). For Spinoza, affection is the impact one body exerts through an action on another body and refers to the impacted state of the body (2011: 242). Affect, however, refers to the lived, experienced passage of one state of the body to another state of it (2011: 134). Since it is the transition from one state to another that causes an affect, different states can be differentiated from each other, analysed, and evaluated conclusively. In relation to Sattouf, this would mean that his monochrome choice of colours and the caricaturing manner of representation have a direct effect on the body of the reader, who perceives this repetitive representation as unambiguous 
and one-sided. This possibly triggers the affect of resistance and the desire for a way out of the one-sidedness and monotony. I argue that this affect is more than a sensation. It is a reaction to a change of sensations which can be perceived and as a perception analysed. According to the Spinozist analysis of Moira Gatens and Genevieve Lloyd (2002), it is precisely this analysis of a changed perception, made possible by affect, that leads to an expansion of our knowledge and to a more appropriate experience of the world, since it does not take a quasi-origin-the effect of one body on another, its affection-as the object of reflection, but can include the effect of an affection in its analysis. With regard to Sattouf, this would mean that the eternal recurrence of the same stereotype provides an opportunity to firstly analyse the evoked feelings, and then to ethically look for alternatives-for the characters, for the representations of nations. It is precisely this enabling force of affects that has prompted me to introduce 'figures of thought'. Namely, that the potential of affects is not determined by their novelty alone, which is highlighted in Deleuze and Guattari's conceptualisations in What is Philosophy (1994), but by the analytical possibilities they open up and make available to thought and thinking through stylistic and narrative figures within the graphic text.

Persepolis, on the other hand, as critical readings have repeatedly emphasised, is concerned precisely with unmasking hardened ideas about 'the Orient' by pointing out visually and narratively the permeability of cultural and national borders (cf. Naghibi et al., 2005; Madella et al., 2013). An example of this would be the globally circulating pop culture, which finds its way into Marjane's life with pop music, branded clothes and star cuts, all of which she passionately desires (Satrapi, 2003: 126-29). Furthermore, Satrapi integrates readers into global resistance narratives. Marx, Lenin, Che Guevara, as well as Rezai and Ashraf find their way into visual and narrative layers (Ibid: 12). Satrapi skilfully transforms these icons of resistance into Marjane's childhood idols and thus anchors them in the narrative. Sometimes Satrapi also revisits stories of resistance and persecution before the eyes of the reader, which detach themselves from a character's perspective and are independent fragments of a superordinate, metafictional story.

One evening, for example, Marjane overhears her parents talking about the burning of the Rex cinema by henchmen of the Shah's regime: a fire that claimed 400 lives (Satrapi, 2003: 14). On the following picture page, this fire is depicted full-page as an inferno and is backed up by a journalistic source, the BBC (Ibid: 15). This image cannot originate from Marjane's perception, as she was not present at the cinema: it is, therefore, an example of a metafictional, omniscient narrative perspective into which the reader is suddenly integrated. Similarly, prison doors and mass graves open for the reader's perception elsewhere, and demonstrations (p. 76), 
battle graves (pp. 102-03), torture chambers (p. 51), executions (p. 125) are shown which Marjane never visited. Marjane serves, in other words, as a springboard for telling stories of persecution and resistance, but without a perpetrator's perspective, taking sides for the persecuted, oppressed and damned of this earth.

Deleuze wrote in Cinema 2. The Time Image (2001) that fabulation is 'not an impersonal myth, but neither is it a personal fiction' (Ibid: 222).iii Rather, fabulation has the function of expressing within a dominant language 'an impossibility of living under domination' (p. 223). For him, this impossibility is expressed when fictional figures cross the border that would 'separate his private business from politics' (p. 222). Only then could collective statements be produced that are directly political, even if they cannot revolutionise ruling power relations, but only express their intolerability. If Sattouf, through his use of colour, has made it clear that clear-cut attributions are unbearable due to their rigidity, Satrapi's omniscient and partisan perspective allows her to perceive domination as untenable.

In summary, it can be concluded that neither Satrapi's nor Sattouf's biographical characters serve to tell a life story. Satrapi and Sattouf's narrative perspectives, their historical references and the stylistic devices used undermine the autobiographical pact and relate directly to the present of the implied reader. Sattouf's little Riad and Satrapi's Marjane are fictional, artificial, and artistic figures that, as a caricature or as a point of identification, relate social ideas or want to evoke them in a futureoriented way. The two graphic narratives challenge national selfconstructions as everyday myths so as to construct and to appeal to readers. This is achieved by their 'figures of thought' which are colour and perspective, next to their line-work and a deconstruction of genre. Their life-stories bring experiences of migration and mobility closer, emphasise the unbearable and question the course of the world. Satrapi and Sattouf record myths and create figures of thought which, while not cracking the familiar firmament, nevertheless show that 'under the different disks that are sun and moon' (Brecht, 1981: 1129-130; my translation) it is up to us creatures to confront the unbearable. 
Doro Wiese, $\mathrm{PhD}$, is a WIRL research fellow at the Institute of Advanced Study, University of Warwick. Facilitated by various grants such as a Marie Sklodowska Curie scholarship of the European Union, she was trained in literary studies, film studies, and cultural studies at the University of Hamburg and Utrecht University. She holds a PhD cum laude (granted only to the top 3-5\% of researchers) from Utrecht University.

\section{References}

Andersen, R. S., Vuori, J. A. and Guillaume, X. (2015). Chromatology of security: Introducing colours to visual security studies. Security Dialogue, 46 (5), pp. 440457. DOI: $10.1177 / 0967010615585106$ [Accessed: 10 October 2020].

Anderson, Benedict. (2016). Imagined Communities: Reflections on the Origin and Spread of Nationalism. Revised edition. London: Verso.

Baetens, J. and Frey, H. (2015). The Graphic Novel: An Introduction. Cambridge: Cambridge University Press.

Baetens, J. (2018). From Black \& White to Color and Back: What Does It Mean (not) to Use Color? College Literature, 38 (3), pp. 111-128. Available at: https://www.jstor.org/stable/41302875 [Accessed: 10 October 2020].

Barthes, R. (1957). Mythologies. Paris: Seuil (Collection Pierres vives).

Bogue, R. (2010). Deleuzian Fabulation and the Scars of History. Edinburgh: Edinburgh University Press (Plateaus).

Bonnefoy, L. (2015). L'Aarabe du futur' ou la force des préjugés. Orient XXI, 23 January. Available at: https://orientxxi.info/lu-vu-entendu/l-arabe-du-futur-oula-force-des-prejuges, 0784 [Accessed: 4 October 2020].

Brecht, B. and Willett, J. (1978). Brecht on Theatre: The Development of an Aesthetic. New York: Hill and Wang.

Brecht, B. (1981). Die Liebenden. In Die Gedichte von Brecht in einem Band. Frankfurt am Main: Suhrkamp.

Chrisafis, A. (2016). Riad Sattouf interview: 'I didn't want to be the guy of Arab origin who makes comics about Arab people'. The Guardian, 30 September. Available at: https://www.theguardian.com/books/2016/sep/30/riad-sattoufinterview-graphic-novelist [Accessed: 14 May 2020].

Chaney, M. A. (2011). Graphic Subjects. Critical Essays on Autobiography and Graphic Novels. Madison: University of Wisconsin Press.

Chute, H. (2008). The Texture of Retracing in Marjane Satrapi's Persepolis. WSQ: Women's Studies Quarterly, 36 (1-2), pp. 92-110. DOI: 10.1353/wsq.0.0023. 
Cohn, D. (1990). Signposts of Fictionality: A Narratological Perspective. Poetics Today, 11 (4), pp. 775-804. DOI: 10.2307/1773077.

Cooke, R. (2016). The Arab of the Future 2 - Terrifying School Days in Syria. The Guardian, 27 September. Available at:

https://www.theguardian.com/books/2016/sep/27/the-arab-of-the-futurevolume-2-review-raid-sattouf-terrifying-school-days [Accessed: 14 May 2020].

Deleuze, G. and Guattari, F. (1994). What is Philosophy? New York: Columbia University Press (European Perspectives).

Deleuze, G. (2001). Cinema 2. The Time-Image. Translated by H. Tomlinson and R. Galeta. Minneapolis: University of Minnesota Press.

Dueben, A. (2016). Interview: Riad Sattouf on Growing Up Between the Lines of France and Syria in The Arab of the Future. Comics Beat, 21 December.

Available at: https://www.comicsbeat.com/interview-riad-sattouf-on-growingup-between-the-lines-of-france-and-syria-in-the-arab-of-the-future/ [Accessed: 11 May 2020].

Ernst, S. (2005). Die Mullahs töten unsere Träume. Interview mit Comic-Autorin Satrapi. Spiegel Online, 10 February. Available at:

https://www.spiegel.de/kultur/literatur/interview-mit-comic-autorin-satrapidie-mullahs-toeten-unsere-traeume-a-340578.html [Accessed: 5 May 2020].

Friedman, S. S. (2013). Wartime Cosmopolitanism: Cosmofeminism in Virginia Woolf's Three Guineas and Marjane Satrapi's Persepolis. Tulsa Studies in Women's Literature, 32 (1), pp. 23-52. Available at:

https://www.jstor.org/stable/43653363.

Gatens, M. and Lloyd, G. (2002). Collective Imaginings: Spinoza, Past and Present. London: Routledge.

Genette, G. (1990). Fictional Narrative, Factual Narrative. Poetics Today, 11 (4), pp. 755-774. DOI: 10.2307/1773076.

Gilmore, L. (2011). Witnessing Persepolis Comics, Trauma, and Childhood Testimony. In: Chaney, M. A., ed., Graphic Subjects: Critical Essays on Autobiography and Graphic Novels. Wisconsin: University of Wisconsin Press, pp. 157-164.

Groensteen, T. (2013). Comics and Narration. Translated by Ann Miller. Jackson: University Press of Mississippi.

Hatfield, C. (2005). Alternative Comics. An Emerging Literature. Jackson: University Press of Mississippi.

Lejeune, P. (1975). Le pacte autobiographique. Paris: Éditions du Seuil (Collection Poétique).

Löschnigg, M. (2019). 1.11 Narratology. In: Handbook of Autobiography / Autofiction. Berlin and Boston: De Gruyter. DOI: 10.1515/9783110279818-012 [Accessed 04 October 2020]. 
Klepper, M. (2019). 3.2 Autobiographical/Autofictional Comics. In Handbook of Autobiography / Autofiction. Berlin and Boston: De Gruyter. DOI: 10.1515/9783110279818-058 [Accessed 04 October 2020].

McCloud, S. (1994). Understanding Comics. First Harper Perennial edition. New York: William Morrow, an imprint of Harper Collins.

Naghibi, N. and O'Malley, A. (2005). Estranging the Familiar: 'East' and 'West' in Satrapi's Persepolis. ESC: English Studies in Canada, 31 (2), pp. 223-247. DOI: 10.1353/esc.2007.0026.

Madella, T. (2013). Otherness in Marjane Satrapi's Persepolis: The Autobiography and the Graphic Novel as a Subversion of the Western Gaze. In: Evans, Jonathan C. and Giddens, Thomas (eds.). Cultural Excavation and Formal Expression in the Graphic Novel, Leiden: Brill, pp. 55-63. DOI:

10.1163/9781848881990 [Accessed 15 October 2020].

Mirakhor, L. (2017). The Future is Here: An Interview with Riad Sattouf, Author of The Arab of the Future. Los Angeles Review of Books, 31 January. Available at: https://lareviewofbooks.org/article/future-interview-riad-sattouf-author-arabfuture/ [Accessed: 11 May 2020].

Pastoureau, M. (2010). Les couleurs de nos souvenirs. Paris: Seuil.

Potet, F. (2015). Riad Sattouf remporte le Fauve d'or à Angoulême pour 'L'Arabe du futur'. Le Monde, 28 September. Available at:

https://www.lemonde.fr/bande-dessinee/article/2015/02/01/riad-sattoufremporte-le-fauve-d-or-a-angouleme-pour-l-arabe-dufutur 4567640 4420272.html [Accessed: 5 May 2020].

Satrapi, M. (2003). Persepolis 1: The Story of a Childhood. New York: Pantheon, 2003.

--- (2004). Persepolis 2: The Story of a Return. New York: Pantheon, 2004.

Sattouf, R. (2015). The Arab of the Future 1: A Graphic Memoir. A Childhood in the Middle East (1978-1984). First U.S. edition. Translated by S. Taylor. New York: Metropolitan Books.

--- (2016). The Arab of the Future 2: A Graphic Memoir. A Childhood in the Middle East (1984-1985). Translated by S. Taylor. London: Two Roads.

--- (2018). The Arab of the Future 3: A Graphic Memoir. A Childhood in the Middle East (1985-1987). Translated by S. Taylor. London: Two Roads.

--- (2019). The Arab of the Future 4: A Graphic Memoir. A Childhood in the Middle East (1987-1992). First U.S. edition. Translated by S. Taylor. New York: Metropolitan Books, Henry Holt and Company, LLC.

Senior, J. (2016). Review: 'The Arab of the Future 2: Back to Syria in 1984'. The New York Times, 19 October. Available at:

https://www.nytimes.com/2016/10/20/books/review-in-the-arab-of-thefuture-2-back-to-syria-in-1984.html [Accessed: 15 October 2020]. 
Shatz, A. (2003). The Native Informant. The Nation, 10 April. Available at: https://www.thenation.com/article/archive/native-informant/ [Accessed: 4 October 2020].

Shatz, A. (2015). Drawing Blood. Memoir of a French-Arabian Cartoonist. The New Yorker (19 October 2015), pp. 58-68.

Spinoza, B. de (2011). The Vatican Manuscript of Spinoza's Ethica, edited by L. Spruit and P. Totaro. Leiden: Brill.

Wiese, D. (2014). The Powers of the False: Reading, Writing, Thinking beyond Truth and Fiction. Evanston, Illinois: Northwestern University Press (Flashpoints).

Wiese, D. (2016). Tinting the Senses, Adjusting the Gaze: Colouring versus CloseUp as a Means to Draw Viewers into Visual Works. Journal of Graphic Novels and Comics, 7 (4), pp. 369-380. DOI: 10.1080/21504857.2016.1180540.

Whitlock, G. (2006). Autographics: The Seeing 'I' of the Comics. Modern Fiction Studies, 52 (4), pp. 965-979. DOI: $10.1353 / \mathrm{mfs} .2007 .0013$

\section{To cite this article:}

Wiese, D., 2020. Figures of Thought in Marjane Satrapi's Persepolis and Riad Sattouf's The Arab of the Future. Exchanges: The Interdisciplinary Research Journal, 8(1), 57-70. Available at: https://doi.org/10.31273/eirj.v8i1.642.

\section{Endnotes}

\footnotetext{
'Among the prizes that The Arab of the Future received are the Grand Prix RTL de la bande dessinée in 2014, the Fauve d'or du Festival d'Angoulême in 2015, and the Los Angeles Book Prize in 2015.

ii For instance, Persepolis 1 was named Comic of the Year at the Frankfurt Book Fair in 2004, and Satrapi, like Sattouf, won for Persepolis 1 and 2 prizes at the Festival d'Angoulême.

iii In Cinema 2. The Time Image, the English translators Hugh Tomlinson and Robert Galeta have chosen to translate 'fabulation' as 'story-telling'. However, since Deleuze refers to a concept by Bergson (see Bogue 2010), I have chosen to use a terminology more in line with the original version.
} 